\title{
Oral complications in patients receiving head and neck radiation therapy: a literature review
}

\author{
Complicações bucais em pacientes expostos à radioterapia de cabeça e pescoço
}

Janaine SARI ${ }^{1}$

Karen Silva NASILOSKI ${ }^{2}$

Ana Paula Neutzling GOMES 3

\begin{abstract}
Oral cancer is a relatively common disease worldwide and its incidence rate has increased over the years. In Brazil, thousands of new cases emerge and the dental surgeon is the professional who diagnoses, prevents, intervenes in and instructs patients in regard to the disease, its treatment and related complications. There is no current form of systemic treatment able to destroy abnormal cells without causing harm or death to normal cells. Surgery combined with radiation is one of the most common treatments for malignant tumors in the head and neck. This modality of treatment has resulted in high rates of cure and survival. There are, however, severe side effects, causing morbidities and reducing patients' quality of life. Hence, this study's aim was to perform a literature review addressing the main complications arising form radiation therapy while emphasizing the conduct of dental surgeons in the face of these changes.
\end{abstract}

Indexing terms: Head and neck neoplasms. Mucositis. Radiation therapy.

\section{RESUMO}

O câncer bucal é uma doença relativamente comum a nível mundial e que vem aumentando a sua incidência ao longo dos anos. No Brasil, milhares de novos casos surgem e o cirurgião-dentista é o profissional que precisa estar preparado para diagnosticar, prevenir, intervir e orientar os pacientes quanto a doença, seu tratamento e as complicações inerentes ao mesmo. Não existe, atualmente, uma forma de tratamento sistêmico para o câncer que tenha a capacidade de destruir as células alteradas, sem causar dado ou a morte das células normais. A cirurgia combinada com a radioterapia é uma das formas mais comuns para tratamento dos tumores malignos de cabeça e pescoço. Essa modalidade de tratamento tem obtido altos índices de cura e sobrevida aos pacientes, porém, os efeitos colaterais existentes são graves e capazes de provocar morbidade aos pacientes, diminuindo a sua qualidade de vida. Desse modo, o objetivo do trabalho é realizar uma revisão de literatura sobre as principais complicações decorrentes do tratamento radioterápico, enfatizando a conduta do cirurgião-dentista frente a estas alterações.

Termos de indexação: Neoplasias de cabeça e pescoço. Mucosite. Radioterapia.

\section{INTRODUCTION}

Oral cancer has been a major focus of interest among researchers from the health field because, if not diagnosed until an advanced stage, it can lead to high rates of morbidity or even be fatal'.

The National Cancer Institute (INCA) estimated 576,000 new cases of cancer in Brazil in 2014. According to the INCA, cancer in the oral cavity accounts for $11.54 \%$ of cancer in men. It is the $5^{\text {th }}$ most frequent cancer among men and the $12^{\text {th }}$ most frequent cancer among women, i.e., it accounts for $3.92 \%$ of cancer cases among women².

Because a high percentage of these cancer patients are diagnosed in advanced stages, the treatment is increasingly invasive, including surgery, radiation therapy, or chemotherapy applied in isolation or in association with other treatment, depending on the tumor's site, histological degree, clinical stage, and the patient's physical condition'. Neville et al. ${ }^{3}$ state no systemic treatment for cancer is currently available with the ability to destroy tumor cells without causing the death of at least some normal cells. According to Ramos et al. ${ }^{4}$, surgery combined with radiation therapy has been one of the most common treatments for advanced head and neck malignant tumors. Although this therapeutic modality has obtained high levels of cure and greater survival, its side effects are quite severe.

Approximately $60 \%$ of the patients receive radiation therapy to treat head and neck cancer and most receive the combined therapy so that the development of a series of changes is expected to affect the oral cavity ${ }^{5}$.

Treatment with radiation is based on the principle of cytotoxicity against malignant cells and is more effective

\footnotetext{
${ }^{1}$ Prefeitura Municipal de Três Passos, Unidades Municipais de Saúde, Estratégia da Saúde da Família. Rua Piratini, 553, Distrito de Padre Gonzales, 98620-000, Três Passos, RS, Brasil. Correspondência para / Correspondence to: J SARI. E-mail: <janainesari@yahoo.com.br>.

${ }^{2}$ Prefeitura Municipal de Rio Grande. Rio Grande, RS, Brasil.

${ }^{3}$ Universidade Federal de Pelotas, Faculdade de Odontologia. Pelotas, RS, Brasil.
} 
during cell mitosis and nonspecific to all cells exposed to radiation. As a consequence, non-neoplastic cells exposed to radiation are subjected to destruction, a fact that limits the dosage to be used in cancer therapy ${ }^{6}$. The main side effects of radiation therapy applied to the oral cavity are dermatitis, mucositis, loss of taste, xerostomia, osteoradionecrosis, trismus, candidiasis, and radiation cavities, among others.

This study's aim was to perform a literature review regarding oral changes accruing from radiation therapy, emphasizing the procedures used by dental surgeons to respond to such changes.

\section{LITERATURE REVIEW}

When radiation therapy and/or chemotherapy are prescribed to treat head and neck cancer, the patient has to undergo a stomatological assessment in order to prevent complications caused by the treatment. Patients also need to be aware that undesirable effects may arise $\mathrm{e}^{7-8}$.

Prior to radiation therapy, the dental surgeon should ask the responsible physician for information regarding the tumor's diagnosis, stage that it is in, the patient's health status, site, dosage, and duration of the radiation therapy 7,9 . The patient also needs to undergo detailed clinical assessment involving intra- and extra-oral structures, in addition to radiographic exams to diagnose potential changes.

Having all this information at hand, the dental surgeon can establish, together with the remaining professionals involved in the treatment, the ideal therapy to eliminate any infectious disease in the oral cavity and keep it healthy ${ }^{10}$. Proper preparation of the oral cavity must be initiated at least two or three weeks prior to the radiation therapy's initiation to enable elimination of infection and traumatic elements, reduce microbial activity and emphasize orientations regarding oral hygiene to the patient.

According to Ragghianti et al. ${ }^{9}$, the intervention in this initial phase involves Radiology, Dentistry, Prosthodontics, Endodontics, Periodontics and Oral and Maxillofacial Surgery. Rough and sharp edges on the teeth or existing restorations are polished and the extraction of any teeth with a doubtful prognosis should be made at least 14 days before the start of radiation therapy, using antibiotics from the day before surgery until the end of healing. All procedures should be designed to avoid all trauma, with the least possible damage to soft and bone tissues in order to promote rapid and complete healing ${ }^{10-11}$.
The side effects of anti-cancer therapy range from mild discomfort and malaise to the development of new neoplasia. For this reason, the patient's motivation is one of the most important variables; there is no one more necessary and important in preventive programs than the patient her/himself 9 .

The main role of the dental surgeon during the time radiation therapy is being administered is to minimize immediate and mediate effects, alleviating undesirable side effects. The main side effects arising from anti-cancer treatment under the scope of dentistry include:

\section{Mucositis}

Mucositis is the most common and first reaction arising from the cancer treatment. Sciubba \& Goldenberg ${ }^{12}$ describe it as an inflammation of the oral mucosa resulting from chemotherapy or ionizing radiation.

The prevalence of oral mucositis resulting from radiation is $36 \%$ to $100 \%$ of patients ${ }^{13}$. During radiation therapy, the first symptoms of mucositis appear with a dosage of radiation equivalent to 1000 CGY, which generally occurs in the first week of treatment ${ }^{6,14}$.

Clinically, mucositis initially manifests as a rash in the oral mucosa, however, it often progresses to skin loss and ulceration. Ulcers are typically covered by a white pseudomembrane. Lesions last from 2 to 4 weeks and tend to regress after radiation therapy ${ }^{15}$. The most frequent symptoms include pain, dysphagia, and odynophagia, resulting in anorexia and difficulty speaking. Pain is usually intense and sometimes uninterrupted ${ }^{16}$.

According to Epstein \& Schubert ${ }^{17}$, pain associated with mucositis depends on the degree of tissue damage, sensitivity of the nervous receptors, and the production of mediators of inflammation and pain. Some authors note that mucositis is more accentuated among patients without good oral hygiene practices. In these cases, the action of opportunistic viruses, fungi, and, generally gramnegative bacteria, aggravate even more damage caused to the mucosa, worsening the risk of pain and necrosis. Other factors that influence how severe mucositis will be are dosage of radiation, dosage and type of chemotherapy drugs, the patient's overall health condition, and the use of local irritants such as alcohol, tobacco, and spicy foods ${ }^{18-20}$.

Many substances, such as oral steroids, vitamin $\mathrm{E}$, and oral glutamine supplements, are being tested to prevent and treat oral mucositis ${ }^{21-22}$. The palliative treatment consists of topical analgesics, mouthwash with chlorhexidine to reduce the risk of infection, and mouthwash with benzydamine hydrochloride to alleviate 
pain, or systemic analgesics ${ }^{10}$. The use of low-power laser therapy has been efficacious in controlling mucositis symptoms. Studies conducted by Arora et al..$^{13}$ report that laser treatment applied prophylactically during radiation therapy may reduce the severity of oral mucositis. It promotes the release of prostaglandins, which enables anti-inflammatory action, and promotes the release of endorphins that help to control the pain ${ }^{23}$. The effects of mucositis only regress after irradiation ceases but they do not leave sequelae.

\section{Dermatitis}

According to Neville et al. $^{3}$ acute radiation dermatitis in the areas where radiation is applied is common and varies according to the intensity of the treatment. Moderate radiation causes erythema and edema, combined with skin loss and ulcers. When it becomes chronic, it is characterized by bright, atrophic, necrotic areas, with telangiectasia, disappearance of follicular structures, or ulcers. Patients must provide good care for the skin, keeping it well-hydrated and use sun protection to avoid even more damage.

\section{Loss of taste}

Also called hypogeusia. Taste buds are very sensitive to radiation, especially fungiform and circumvallate papillae, thus, patients may partially or totally lose taste during radiation therapy. Change of taste is a direct effect of radiation on the taste corpuscles and changes in saliva, with a decrease of $50 \%$ in the perception of bitter and acid tastes ${ }^{15}$. Loss of taste associated with pain, dysphagia, hyposalivation and depression lead to loss of pleasure in eating, loss of appetite, and malnutrition ${ }^{24-25}$.

Hypogeusia can be perceived two weeks after radiation therapy. In most cases, cells regenerate within 4 months after treatment, though it may be permanent in some cases. Other patients may experience dysgeusia, i.e., changed taste, which may be recovered with the use of zinc supplements ${ }^{25}$.

\section{Hyposialia}

Hyposialia, which results in xerostomia (dry mouth), is a common and persistent complication arising from head and neck radiation therapy. It consists of decreased saliva secretion and usually initiates after a dosage from 1,000 to 2,000 cGY, which corresponds to the second week of treatment ${ }^{4}$. The prevalence of xerostomia among patients with head and neck cancer who had major salivary glands involved in the area of radiation is from $94 \%$ to $100 \%{ }^{12}$.
Salivary hypofunction is directly related to the dosage of radiation and also to the quantity of salivary gland tissue irradiated. Silverman ${ }^{24}$ clarifies that the exposure of major salivary glands to the beam of ionizing radiation may induce fibrosis, acinar atrophy, and gland cell necrosis. Obviously, the higher the dosage of radiation, the worse the prognosis for xerostomia, though palliative procedures may minimize symptoms. According to Neville et al. ${ }^{3}$, changes start to occur one week after the beginning of the treatment, with a marked decrease in salivary flow.

Residual saliva becomes viscous and has less lubrication power due to a decrease in the amount of mucin. There is also a marked decrease in $\mathrm{pH}$, which means saliva becomes more acid due to changes in the concentration of calcium, sodium and bicarbonates ${ }^{1}$. This change in saliva and salivary flow can favor increased accumulation of bacterial plaque and the development of xerostomia-related caries, also called "radiation caries" 3 .

Alteration in oral microbiota is very significant when glands undergo changes, mainly occurring as an exchange of non-cariogenic microorganisms for cariogenic microorganisms, predominantly Streptococus mutans and Lactobacilos. Additionally, the population of Actinomyces naeslundi, associated with periodontal disease and root caries, increases after radiation ${ }^{26}$. Therefore, we highlight the importance of controlling bacterial plaque through proper oral hygiene.

Additionally, hyposalivation predisposes patients to opportunistic infections both due to a lack of lubrication, which lowers resistance to fungi of the gender Candida, and a lack of amylase and immunoglobulin A, which increases one's susceptibility to bacterial infection ${ }^{6,27-28}$.

Lesions caused by Candida albicans in the oral mucosa manifest as a coating or patches of white slough that reveal a reddish base if removed. Patients with xerostomia may experience a widespread burning sensation in the mouth, and discomfort and redness in the apex of the tongue. To avoid opportunistic infections such as candidiasis, the patient must use mouthwash with chlorhexidine at $0.2 \%$ or $0.1 \%$ in aqueous solution'.

The management of patients with candidiasis includes frequent use of mouthwash with hydrogen peroxide or the use of topical antifungals such as nystatin, ketoconazole, and chlorhexidine ${ }^{10}$. Chlorhexidine should be used at least 30 minutes before or after the use of any antifungal to ensure its effectiveness.

The normal salivary function of patients who undergo radiation tends to return from 2 to 6 months or up to one year after the radiation therapy ceases. It, 
however, may take from 1 to 2 years or never return to normal levels if the parotid glands are involved ${ }^{1,29}$.

Frequent use of mouthwash or sips of water and also sugar-free gums help to partially control radiationinduced xerostomia. A flexible solution for the treatment of xerostomia would be the use of salivary glands stimulators, such as pilocarpine at $2 \%$, or saliva substitutes or artificial saliva, which are palliative substances that alleviate discomfort caused by xerostomia ${ }^{12}$.

Pilocarpine is an agent that stimulates the salivary glands and has been suggested to reduce damage to glands during radiation therapy ${ }^{30}$. Pilocarpine hydrochloride has been effective in stimulating saliva production in some patients, though it is only efficient if the glands present some residual functioning ${ }^{31}$.

Foods rich in ascorbic acid, malic or citric acid stimulate the glands to increase salivary flow; acidity, however, may harm oral tissues, aggravate mucositis and demineralize teeth ${ }^{8}$.

\section{Radiation caries}

Radiation caries (rampant caries) is an alteration that develops after radiation therapy and is characterized by rapid development and onset is generally on the tooth's cervical region. It develops much faster than conventional caries, as it reaches the dentin within a month, whereas tooth decay takes one year, on average, in non-irradiated patients ${ }^{1}$.

Most authors believe that radiation caries results from indirect effects of radiation on teeth such as diminished salivary flow, change in the chemical composition of saliva, and the development of cariogenic microorganisms ${ }^{15}$. Additionally, hyposalivation is always accompanied by a change in eating habits. Doughy foods rich in carbohydrates are more frequently consumed, which favors the development of caries ${ }^{1,32}$.

Some authors, such as Lopes et al. ${ }^{1}$, Salvajoli et al. ${ }^{7}$ and Silverman ${ }^{24}$, however, state that radiation caries may be a result not only of radiation therapy's indirect effects, but also of direct effects on the teeth. These changes would mainly occur on the odontoblasts, reducing the production of reaction dentin. These authors also add that direct irradiation on the teeth may change their organic and inorganic components and, somehow, in a not very explicit manner, make them susceptible to decalcification.

Clinically, the teeth acquire a brittle appearance and enamel chips, easily detaching from them, a situation that is observed approximately three months after the radiation therapy ceases ${ }^{1}$.
Oral hygiene must be very strict, including regular visits to the dentist for examination, prophylaxis and use of fluoride, in addition to care performed at home ${ }^{15}$. Topical fluoride applied daily, either as a mouthwash or in the form of neutral gel (sodium fluoride at $1 \%$ ), is extremely effective. If a carious lesion settles in, its removal and restoration should be performed immediately due to their rapid progression. If it has already destroyed the entire crown and compromised the pulp, endodontic treatment must be implemented to obliterate the duct, leaving the root "buried" in the cavity. Hence, endodontic treatment is important because it controls pain and enables aesthetic and functional recovery of teeth afterwards and prevents osteoradionecrosis, which is beneficial in avoiding tooth extractions ${ }^{33-34}$.

\section{Osteoradionecrosis}

Osteoradionecrosis (bone death) is the most severe and undesirable complication resulting from radiation therapy applied to treat head and neck cancer. It usually manifests from 2 to 3 years after the treament ${ }^{1}$ and its incidence ranges from $1 \%$ to $37.5 \%{ }^{12}$.

Its pathogenesis is related to the formation of hypovascular-hypocellular-hypoxic tissue resulting from irradiation ${ }^{17}$, with consequent spontaneous or traumatic disruption of the oral mucosal barrier, resulting in a nonhealing process. Bone cells and vascularization may be irreversibly damaged and, in many cases, devitalized bone fragments generate bone sequestration ${ }^{35-36}$.

The anatomical site most frequently affected is the mandible because it presents a more compact and dense bone structure and a lower intake of blood flow compared to the jaw ${ }^{7,37}$. The risk is greater among patients with natural dentition and in cases in which teeth are considered treatable but then need to be removed after the therapy.

Clinically, osteoradionecrosis is characterized by exposure of necrotic bone tissue associated with signs and symptoms such as paraesthesia, anesthesia, and secondary infection and the formation of fistula, with a progressive destruction of bone and the development of pathological fractures $^{37}$. An ill-defined radiolucent image without sclerotic margins can be observed in X-rays. Radiopaque images can be seen when there is formation of bone sequestration? ${ }^{7}$.

Treatment of osteoradionecrosis consists of surgical intervention, debridement, and wound care, antibiotic therapy, and hyperbaric oxygenation. If osteoradionecrosis is diagnosed early, local debridement and treatment with antibiotics may succeed ${ }^{12}$. Resection of the necrotic bone 
and hyperbaric oxygen are, however, indicated among patients whose disease has already established ${ }^{12}$. Teeth in poor condition, bone trauma, periodontal disease, combined chemotherapy (systemic immunosuppression), and extractions are risk factors for osteoradionecrosis and, for this reason, should be avoided whenever possible'. Additionally, a proper diet that avoids alcohol and tobacco contributes to the prevention of osteoradionecrosis ${ }^{16}$.

\section{Trismus}

Trismus (lockjaw) is a relatively common complication after irradiation of head and neck cancer. It arises from hypovascularization and fibrosis of the muscle tissue, manifesting from 3 to 6 months after radiation therapy ${ }^{6,38}$. According to Wang et al. ${ }^{38}$, the muscles affected by trismus during cancer treatment are the

\section{REFERENCES}

1. Lopes MA, Coletta RD, Alves FA, Abbade N, Rossi Junior A. Reconhecendo e controlando os efeitos colaterais da radioterapia. Rev Assoc Paul Cir Dent. 1998;52(3):241-4.

2. Brasil. Instituto Nacional do Câncer (INCA). Estimativa 2014: incidência de câncer no Brasil; 2013 [citado 2014 Set 14]. Disponível em : <http://www2.inca.gov.br/wps/wcm/connect/0129ba004 $1 \mathrm{fbbc01}$ aa4fee936e134226/Apresentacao+Estimativa+2014 final+corrigido+tireoide.pdf?MOD=AJPERES\&CACHEID=0129ba 0041fbbc01aa4fee936e134226>

3. Neville B, Damm DD, Allen CM, Bouquot JE. Patologia oral e maxilofacial. $3^{\text {a }}$ ed. Rio de Janeiro: Guanabara Koogan; 2009.

4. Ramos FMM, Terra ER, Brayner SC, Haiter Neto F, Bóscolo FN. O papel do cirurgião-dentista na radioterapia de cabeça e pescoço. Odontol Clín Cientif. 2005;4(2):89-94.

5. Merlano M, Corvo R, Margarino G, Benasso M, Rosso R, Sertoli $M R$, et al. Combined chemoterapy and radiation therapy in advanced inoperable squamous cell carcinoma of the head and neck. The final report of a randomized trial. Cancer. 1991;67(4):915-21.

6. American Academy of Periodontology (AAP). Periodontal considerations in the management of cancer patient. J Pediodontol. 1997;68(8):791-801.

7. Salvajoli JV, Souhami L, Faria SL. Radioterapia em oncologia. São Paulo: Atheneu; 1999.

8. Soares HA, Marcucci G. Osteorradionecrose: avaliação dos fatores de risco. Rev Odontol Univ São Paulo. 1996;10(1):9-14.

9. Ragghianti MS, Greghi SLA, Capelozza ALA, Resende DRB. Tratamento radioterápico: Parte II - estratégias de atendimento clínico. Salusvita. 2002;21(1):87-96. masticatory or temporomandibular muscles. Tonic muscle spasms with or without fibrosis of the mastication muscles and TMJ (temporal-mandibular joint) can be minimized or prevented with jaw-opening exercises ${ }^{3}$.

\section{FINAL CONSIDERATIONS}

Radiation therapy is a widely used resource to treat cancer. Because it is an unspecific therapy, however, nonneoplastic cells are also affected by the treatment. Tissues in the oral cavity are harmed in many ways, which has a negative impact on the patient's oral and overall health. Hence, dental surgeons are required to be aware of such effects to prevent them and to provide proper treatment to improve patients' quality of life before, during and after cancer treatment.
10. Hancock PJ, Epstein BJ, Sadler GB. Oral and dental management related to radiation therapy for head and neck cancer. J Can Dent Assoc. 2003;69(9):585-90.

11. Jansma J, Vissink A, Spijkervet FK, Roodenburg JL, Panders AK Vermey A, et al. Protocol for the prevention and treatment of oral sequelae resulting from head and neck radiation therapy. Cancer. 1992;70(8):2171-80.

12. Sciubba JJ, Goldenberg D. Oral complications of radiotherapy. Lancet Oncol. 2006;7(2):175-83. doi:10.1016/\$1470-2045(06)70580-0

13. Arora H, Pai KM, Maiya A, Vidyasagar MS, Rajeev A. Efficacy of He-Ne laser in the prevention and treatment of radiation therapy induced oral mucositis in oral cancer patients. Oral Surg Oral Med Oral Pathol Oral Radiol Endod. 2008;105(2):180-6. doi: 10.1016/j.tripleo.2007.07.043

14. Caielli C, Martha PM, Dib LL. Seqüelas orais da radioterapia: atuação da odontologia na prevenção e tratamento. Rev Bras Cancerol. 1995:41(4):231-41.

15. Goursand D, Borges CM, Alves KM, Nascimento AM, Winter RR Martins LHPM, et al. Sequelas bucais em crianças submetidas à terapia antineoplásica: causas e definição do papel do cirurgiãodentista. Arq Odontol. 2006;42(3):161-256.

16. Fischer DJ, Epstein JB. Management of patient who have undergone head and neck cancer therapy. Dent Clin North Am. 2008;52(1):39-60. doi:10.1016/j.cden.2007.09.004

17. Epstein JB, Schubert MM. Oral mucositis in myelossupressive cancer therapy. Oral Surg Oral Med Oral Pathol Oral Radiol Endod.1999;88(3):273-6.

18. Joyston-Bechal S. Prevention of dental diseases following radiation therapy and chemotherapy. Int Dent $J$. 1992;42(1):47-53.

19. Escalona LA, Acevedo AM. Xerostomia: diagnóstico y tratamiento. Acta Odontol Venez. 1990;28(1):37-40. 
20. Felder RS, Millar SB, Henry RH. Oral manifestations of drug therapy. Spec Care Dent. 1998;4(3):119-24. doi: 10.1111/ j.1754-4505.1988.tb00712.x

21. Klimberg VS, Souba WW, Dolson DJ, Salloum RM, Hautamaki RD, Plumley DA, et al. Prophylactic glutamine protecs the intestinal mucosa from radiation injury. Cancer. 1990;66(1):62-8.

22. Sonis ST, Eilers JP, Epstein JB, LeVeque FG, Liggett WH Jr, Mulagha MT, et al. Validation of a new scoring system for the assessment of clinical trial research of oral mucositis induced by radiation or chemotherapy. Cancer. 1999;85(10):2103-13.

23. Migliorati C, Massumoto C, Eduardo FP, Muller KP, Carrieri $T$, Haypek $\mathrm{P}$, et al. The use of low energy lasertherapy in oral mucositis. J Oral Laser Appl. 2001;1:97-101.

24. Silverman S. Oral cancer: complications of therapy. Oral Surg Oral Med Oral Pathol Oral Radiol Endod. 1999;88:122-6.

25. Wiseman $M$. The treatment of oral problems in the palliative patient. J Can Dent Assoc. 2006;72(5):453-8.

26. Moroni P. Pacientes irradiados: reabilitação buco facial. São Paulo: Panamed; 1982.

27. Finlay PM, Richardson MD, Robertson AG. A comparative study of the efficacy of fluconazole and amphotericin B in the tretment of orofaryngeal candidosis in patient undergoing radiation therapy for head and neck tumours. $\mathrm{Br} J$ Oral Maxillofac Surg.1996;34(1):23-5. doi:10.1016/S0266-4356(96)90130-8

28. Brown LR, Dreizen S, Handler S, Johnston DA. Effects of radiation-induced xerostomia on human oral micriflora. J Dent Res.1975;54(4):740-50. doi: 10.1177/00220345750540040801

29. Engelmeier RL, King GE. Complications of head and neck radiation therapy and their management. J Prosthet Dent. 1983;49(4):514-22.

30. Gornitsky M, Shenouda G, Sultanem K, Katz H, Hier M, Black $M$, et al. Double-blind randomized, placebo-controlled study of pilocarpine to salvage salivary gland function during radiation therapy of patient with head and neck cancer. Oral Surg Oral Med Oral Pathol Oral Radiol Endod. 2004;98(1):45-52. doi:10.1016/j.tripleo.2004.04.009
31. Hawtorne M, Sullivan K. Pilocarpine for radiation-induced xerostomia in head and neck cancer. Int J PalliatNurs. 2000;6(5):22832. doi: http://dx.doi.org/10.12968/ijpn.2000.6.5.8924

32. Magalhães MG. Cárie de radiação: prevenção e tratamento. In: Kowalski LP, Dib LL, Ikeda MK, Ade C. Prevenção, diagnóstico e tratamento do câncer bucal. São Paulo: Frôntis; 1999. p. 441-4.

33. Andrade CR, Lopes SMP, Coletta RD, Vargas PA, Lopes MA. Tratamento endodôntico em pacientes submetidos a radioterapia na região de cabeça e pescoço. Rev Assoc Paul Cir Dent. 2003;57(1):43-6.

34. Bueno YC, Carvalho MB. Osteorradionecrose de mandíbula em pacientes com câncer de boca. Rev Bras Med Otorrinolaringol. 1997;4(5):169-74.

35. Clayman L. Management of dental extrations in irradiated jaws: a protocol without hyperbaric oxigen therapy. J Oral Maxillofac Surg. 1997;55(3):275-81. doi: 10.1016/S0278-2391(97)90542-5

36. Curi MM, Dib LL. Osteoradionecrosis of the jaws: a retrospective study of the background factors and treatment in 104 cases. J Oral Maxillofac Surg. 1997;55(6):540-4.

37. Lalla RV, Sonis ST, Peterson DE. Management of oral mucositis in patients who have cancer. Dent Clin North Am. 2008;52(1):6177. doi: 10.1016/j.cden.2007.10.002

38. Wang CJ, Huang EY, Hsu HC, Chen HC, Fang FM, Hsiung CY. The degree and time-course assessment of radiation-induced trismus occurring after radiation therapy for nasopharyngeal cancer. Laryngoscope. 2005;115(8):1458-60. doi: 10.1097/01. mlg.0000171019.80351.46 